\title{
Developing stand transpiration model relating canopy conductance to stand sapwood area in a Korean pine plantation
}

\author{
Juhan Park ${ }^{(1-2)}$, \\ Sungsik $\mathrm{Cho}^{(3)}$, \\ Minkyu Moon ${ }^{(4)}$, \\ Daun Ryu ${ }^{(2)}$, \\ Hyun Seok Kim ${ }^{(1-2-3-5)}$
}

\begin{abstract}
With increasing concern for forest water use and anthropogenic alteration of forest structures, understanding the effects of structural changes in forests on transpiration is important. Our aim is to develop a stand transpiration model relating canopy conductance with stand sapwood area (SA) and environmental conditions for assessing the interannual variation in stand transpiration. The stand transpiration model is developed based on multiplicative empirical $G_{c}$ estimations at eight Korean pine stands with different SAs. The model integrated the response of stomatal conductance to various environmental variables as vapor pressure deficit $(D)$, photosynthetic active radiation $(Q)$, air temperature $\left(T_{\mathrm{a}}\right)$, and soil water content $(\theta)$. The reference $G_{\mathrm{c}}\left(G_{\mathrm{c}}\right.$ at $\left.D=1 \mathrm{kPa}\right)$ and stomatal sensitivity to $D$ was found to have a significant relationship with the SA, whereas other parameters like stomatal sensitivity to $Q$ or $T_{\mathrm{a}}$ did not show significant relationships with it. The $G_{c}$ model successfully reproduced changes in stand transpiration with changes in SA and climatic conditions. As this model uses SA, a simple and easily measurable structural variable, it can be easily applied to other Korean pine forests and can help estimate the spatial and temporal variations in stand transpiration.
\end{abstract}

Keywords: Sapwood Area, Canopy Conductance, Stand Transpiration, Empirical Model

\section{Introduction}

Forest stand structures, such as standing biomass, stand density, and species composition are the important factors controlling forest water use and yield. Many studies have confirmed the effects of structural changes in forests, by natural disturbance or forest management practices, on forest water balance (Hornbeck et al. 1993, Simo-

(1) National Center for Agro Meteorology, Seoul (Rep. of Korea); (2) Department of Forest Sciences, Seoul National University, Seoul (Rep. of Korea); (3) Interdisciplinary Program in Agricultural and Forest Meteorology, Seoul National University (Rep. of Korea); (4) Department of Earth and Environment, Boston University, Boston, MA (USA); (5) Research Institute for Agriculture and Life Sciences, Seoul National University, Seoul (Rep. of Korea)

\section{@ Hyun Seok Kim}

(cameroncrazies@snu.ac.kr)

Received: Nov 12, 2019 - Accepted: Feb 08, 2021

Citation: Park J, Cho S, Moon M, Ryu D, Kim HS (2021). Developing stand transpiration model relating canopy conductance to stand sapwood area in a Korean pine plantation. iForest 14: 186-194. - doi: 10.3832/ifor3291014 [online 2021-04-14]

Communicated by: Rossella Guerrieri nin et al. 2007). Important forest structural properties that regulate forest water balance have been identified, and one of the most sensitive structural parameters in determining the spatial heterogeneity of forest water use and yield is the spatial variation of stand sapwood area (Vertessy et al. 2001, Benyon et al. 2017). Sapwood area is highly correlated with the index of the stand leaf area (Medhurst \& Beadle 2002). In addition, the easiness of measurement makes the sapwood area a useful index for estimate transpiration over a large area.

However, using a stand sapwood area alone fails to estimate interannual variations in forest water use. In short term, large temporal variation in stand transpiration is mainly owing to the physiological regulation of transpiration by controlling stomatal conductance under various climatic conditions (Tang et al. 2006). Trees reduce the stomatal conductance to prevent excessive water loss under drought conditions and maintain internal water potentials within the operative range. In addition, adjustments of the tree structure to climatic conditions control temporal variability of transpiration at a long-time scale. For example, trees tend to allocate more to conducting tissue under drier conditions, which changes in leaf to sapwood area ratios (Cosme et al. 2017). These sources of spatial and temporal variations can be connected through canopy conductance $\left(G_{c}\right)$, as $G_{c}$ is mainly correlated by both stand leaf area index (and sapwood area) and climatic conditions.
To estimate $G_{c}$, empirical and mechanistic models have been used. Mechanistic models consider the response of $G_{c}$ against internal physiological processes in plants, such as the regulation of stomatal guard cells by the ion channel and signalling (Wang et al. 2012). On the contrary, empirical models rely on the observed responses of $G_{c}$ to variations in environmental conditions, and do not provide any specific physiological interpretations, but have been employed primarily at field-level analysis due to their simplicity and effectiveness (Oren et al. 2001, Blanken \& Black 2004). For example, multiplicative models use a set of limiting functions to modify the maximum conductance to account for the empirical relationships among environmental variables (Jarvis 1976).

To develop the empirical models, continuous measurements of $G_{c}$ under various environmental and structural conditions are needed. Due to the difficulties in directly measuring $G_{c}$, indirect measurements from stand transpiration by using sap flux density measurement are widely used (Granier et al. 2000b, Blanken \& Black 2004, Kumagai et al. 2008). In pine species, also, large variations in physiological regulation with stand structural properties or climatic conditions were analysed by sap flow measurements in large geographical areas (Poyatos et al. 2007a, Tor-ngern et al. 2017). Under moist conditions, the reference $G_{c}$ increased with leaf area index until saturation regardless of soil types (Tor-ngern et al. 2017). The $G_{c}$ sensitivity to vapor pressure 
deficit and soil moisture deficit increased with summer evaporative demand as well (Poyatos et al. 2007a). These sap flux measurements are suitable for areas with complex terrain structures like Korean forests and could be used in developing and validating stand transpiration estimates by empirical model, which is enabling reliable estimation of forest water use. This is important for forest management planning because forest transpiration mainly controls the water yield (Caldwell et al. 2016).

In this paper, we developed a model that connects stand transpiration with stand structural attributes and environmental conditions. The model estimated stand transpiration was validated with calculated stand transpiration by upscaling measured sapflux density during the four consecutive growing seasons in even-aged Korean pine (Pinus koraiensis) plantation. Our objectives were to (1) find the main controlling environmental variables in stand transpiration, (2) relate changes of model parameter values with stand sapwood area variability, and (3) test the model applicability under diverse environmental conditions.

\section{Material and methods}

\section{Study sites}

The study was conducted at Mt. Taehwa in central Korea $\left(37.18^{\circ} \mathrm{N}, 127.18^{\circ} \mathrm{E}, 190 \mathrm{~m}\right.$ a.s.l.). The experiments were conducted at eight sites with different stand densities (SDs), basal areas (BAs), and sapwood areas (SAs - Tab. 1). The experiment sites were located adjacent each other, and under the same environmental conditions. The mean annual temperature at the nearest weather station is $11.4 \pm 0.6^{\circ} \mathrm{C}$, and the mean annual precipitation is about $1355.8 \pm$ $300.2 \mathrm{~mm}$, where most of the precipitation occurs during the summer season due to the monsoon climate. Soil is loam generated from granite mixed with gneiss mother rock. Each experimental site was 0.04 ha and the distance among nearest plots was $5 \mathrm{~m}$ and the maximum distance among plots was $30 \mathrm{~m}$. They featured even-aged

Tab. 1 - Stand characteristics of experimental plots. Stand density (SD), basal area (BA), and sapwood area (SA) are expressed per hectare, diameter at breast height (DBH) is expressed stand arithmetic means \pm 1 standard error (SE), and leaf area index (LAI) estimated by allometric relationship on March 2012 is expressed leaf area per ground area.

\begin{tabular}{cccccc}
\hline Plot & $\begin{array}{c}\text { SD } \\
(\text { trees ha }\end{array}$ & $\begin{array}{c}\text { BA } \\
\left(\mathbf{m}^{2} \mathbf{h a}^{-1}\right)\end{array}$ & $\begin{array}{c}\text { SA } \\
\left(\mathbf{m}^{2} \mathbf{h a}^{-1}\right)\end{array}$ & $\begin{array}{c}\text { DBH } \\
(\mathbf{c m})\end{array}$ & $\begin{array}{c}\text { LAl } \\
\left(\mathbf{m}^{2} \mathbf{~ m}^{-2}\right)\end{array}$ \\
\hline P1 & 400 & 29.2 & 18.2 & $29.9 \pm 1.5$ & 4.41 \\
\hline P2 & 375 & 26.1 & 16.8 & $29.5 \pm 1.0$ & 2.70 \\
\hline P3 & 300 & 22.2 & 13.9 & $30.4 \pm 1.4$ & 2.69 \\
\hline P4 & 325 & 28.1 & 16.8 & $33.0 \pm 1.0$ & 3.46 \\
\hline P5 & 300 & 27.7 & 16.0 & $34.1 \pm 1.2$ & 2.96 \\
\hline P6 & 400 & 25.6 & 17.0 & $28.3 \pm 1.0$ & 3.89 \\
\hline P7 & 250 & 17.6 & 11.4 & $29.8 \pm 0.9$ & 1.93 \\
\hline P8 & 225 & 14.7 & 9.8 & $28.8 \pm 0.7$ & 2.00 \\
\hline
\end{tabular}

perature differences between upper and lower probes were measured by 30 -second intervals and averaged by 30-minutes. To minimize natural temperature gradient, the probes were installed on the northern side of stems and shielded by light-reflecting covers. The reference probes were installed at least above $120 \mathrm{~cm}$ from the ground, and upper probes were installed vertically 10 to $15 \mathrm{~cm}$ apart from the reference sensors to prevent thermal interferences. To prevent the errors from sensor dislocation caused by stem growth, new sensors were reinstalled at proper depth on high growth trees. For considering treeto-tree variation in $J_{\mathrm{s}}$, we installed the sensors on 12 trees per plot. In addition, radial variations of sap flux density were measured on 4 sample trees covering most of diameter range within study plots. Three sensors per tree were installed radially (0$20,20-40$, and $40-60 \mathrm{~mm}$ ), and measured the radial variation in sap flux density under changes in environmental conditions (Moon et al. 2016).

The temperature differences between the probes were converted into sap flux density by the following equation (Granier 1987 - eqn. 1):

$J_{S}=118.99 \cdot 10^{-6}\left(\frac{\Delta T_{\max }-\Delta T}{\Delta T}\right)^{1.231}$

. Volumetric soil water content $(\theta)$ the top $30 \mathrm{~cm}$ of the soil layer was measured by TDR sensors (CS-616, Campbell Scientific, USA). All the environmental variables were measured by 30-second interval and 30-minutes averaged values were stored. Vapor pressure deficit (D) was calculated from $T_{\mathrm{a}}$ and $\mathrm{RH}$.

\section{Stand transpiration measurement}

Stand transpiration was estimated from sap flux density $\left(J_{\mathrm{S}}\right)$ measured during 4 consecutive growing seasons from 2012 to 2015 by the hand-made Granier-type thermal dissipation probe method (Granier 1987). This method employs two probes, an upper heating probe and a lower reference probe. The upper probe was heated by a constant power $(0.2 \mathrm{~W})$, and the tem-

where $J_{\mathrm{S}}$ is sap flux density $\left(\mathrm{g} \mathrm{m}^{-2} \mathrm{~s}^{-1}\right), \Delta T_{\max }$ is the maximum temperature difference recorded at zero flux, and $\Delta T$ is the temperature difference recorded at each time step. Because coefficients in eqn. 1 are highly sensitive to the applied heat (Granier 1987), constant power ( $0.2 \mathrm{~W}$ ) was supplied to the heating probe. The zero flux was determined by biophysical conditions (night time with low $D,<0.1 \mathrm{kPa}$ ) and stability of $\Delta T$ (less than 0.05 standard deviation changes in $\Delta T$ for 2 hours).

A power failure after a typhoon event caused 20-day data gaps in sap flux density measurements from June 2012 to July 2012. These data gaps were filled using the relationship between $J_{\mathrm{s}}$ and environmental variables. (mean and minimum $r^{2}$ between $J_{s}$ and environmental variables were 0.62 and 0.49 , respectively). At other times during the study periods, single tree data gaps occasionally occurred due to sensor damage. These individual tree data gaps in $J_{S}$ were filled using the linear relationship with other trees in the same plot (mean and minimum $r^{2}$ between trees were 0.96 and 0.83 , respectively).

Daily stand-level transpiration $\left(E_{T}, \mathrm{~mm} \mathrm{~d}^{-1}\right)$ was scaled up by multiplying the measured sapflux density with the relevant sapwood area (eqn. 2):

$E_{T}=\sum_{i=1}^{3} J_{S_{i}} A_{S_{i}} / A_{P}$

where $J s_{i}$ is the daily aggregated sapflux density of the outer- (0-20 mm), mid- (20$40 \mathrm{~mm})$, and inner- $(40-60 \mathrm{~mm})$ sapwood 
(kg m${ }^{-2} \mathrm{~d}^{-1}$ ), respectively, $A_{\mathrm{si}}$ is the relevant sapwood area $\left(\mathrm{m}^{2}\right)$, and $A_{\mathrm{p}}$ is the total stand area $\left(\mathrm{m}^{2}\right)$. Due to little color distinction between heartwood and sapwood, the active sapwood area was determined by the zero-sapflux density depth. The outer $60 \mathrm{~mm}$ of each tree's BA was assumed to be a conductive SA because sap flow across sapwood area deeper than 60 $\mathrm{mm}$ was considered negligible (Moon et al. 2015). On average, outer sapwood transported most (> 80\%) of sap flow. Mid- and inner-sapwood area contributed less than $20 \%$ of sap flow, where sap flux density of mid-sapwood was $13.67 \%$ of outer sap flux density and that of inner sapwood was $6.86 \%$ of outer sap flux density. The sapwood area was selected as the only scaling factor because total needle mass was highly correlated with DBH (Ryu et al. 2014), which in turn showed a high correlation with sapwood area.

\section{Stand transpiration estimation model}

The model development processes consist of three steps. First, $G_{c}$ is calculated from stand transpiration estimated by sap flux density measurements. Second, the limitation in $G_{c}$ according to each environmental variable is analysed. Third, the limit ing function of $G_{c}$ is related to the struc tural parameters (sapwood area), and its applicability to different climatic conditions was tested.

The canopy conductance was estimated by the inversion of the simplified PenmanMonteith equation (Jarvis \& McNaughton 1986, Komatsu et al. 2014). This equation assumes that equilibrium evaporation is negligible, and can be applied to coniferous plantations closely coupled to overhead atmosphere owing to their short characteristic leaf length (Kelliher et al. 1993). The equation expressed $G_{C}$ as (eqn. 3):

$$
G_{C}=\frac{E_{T} \gamma \lambda}{\rho C_{p} D}
$$

where $\rho$ is the density of air $\left(\mathrm{kg} \mathrm{m}^{-3}\right), C_{\mathrm{p}}$ is its specific heat $\left(\mathrm{J} \mathrm{K}^{-1} \mathrm{~kg}^{-1}\right), \mathrm{G}_{\mathrm{c}}$ is canopy conductance $\left(\mathrm{mm} \mathrm{d}^{-1}\right), D$ is vapor pressure deficit $(\mathrm{kPa}), \gamma$ is the psychrometric constant $\left(\mathrm{KPa} \mathrm{K}^{-1}\right)$, and $\lambda$ is the latent heat of water vaporization $\left(\mathrm{J} \mathrm{kg}^{-1}\right)$.

The modeled $G_{c}$ calculated by the relationship between environmental conditions and $E_{\mathrm{T}}$ was used as the reference in the estimation model. This model uses the sensitivity of $G_{c}$ against environmental variables, and a set of limiting function was applied as follows (Jarvis 1976, Harris et al. 2004, Rodrigues et al. 2016 - eqn. 4):

$$
G_{C}=f_{1}(D) \cdot f_{2}(Q) \cdot f_{3}\left(T_{a}\right) \cdot f_{4}(\theta)
$$

where $f_{1}(D), f_{2}(Q), f_{3}\left(T_{a}\right)$, and $f_{4}(\theta)$ are functions expressing the responses of $G_{c}$ to the daily mean vapor pressure deficit $(D)$, photosynthetically active radiation ( $Q$ ), air temperature $\left(T_{\mathrm{a}}\right)$, and soil water contents $(\theta)$, respectively. Each response was modeled as follows (eqn. 5 - eqn. 8 ):

$$
\begin{aligned}
& f_{1}(D)=G_{\text {Cref }}-m \cdot \ln (D) \\
& f_{2}(Q)=\min \left\{\left(\frac{Q}{600}\right)^{\delta}, 1\right\} \\
& f_{3}\left(T_{a}\right)=\left\{\left(\frac{T_{a}-T_{\max }}{T_{\text {opt }}-T_{\min }}\right)\left(\frac{T_{\text {max }}-T_{a}}{T_{\text {max }}-T_{\text {opt }}}\right)\right\}\left(\frac{T_{\text {opt }}-T_{\text {max }}}{T_{\text {opt }}-T_{\min }}\right) \\
& f_{4}(\theta)=\left\{\begin{array}{cl}
\frac{\theta-\theta_{\text {min }}}{\theta_{\text {max }}-\theta_{\text {min }}} & \text { when } \theta<\theta_{\text {min }}<\theta<\theta_{\text {max }} \\
1 & \text { when } \theta>\theta_{\text {max }}
\end{array}\right.
\end{aligned}
$$

where $G_{c r e f}$ is the reference value of $G_{c}$ when $D=1.0 \mathrm{kPa}, m$ is the slope between $G_{c}$ and $\ln (D), \delta$ is the parameter that determines the sensitivity of $Q$ to limitations in $G_{c}, T_{\min }, T_{\max }$, and $T_{\text {opt }}$ are the minimum, maximum, and optimum $T_{a}$ for $G_{c}$, respectively, $\theta_{\min }$ is the soil water content where stomata are completely closed by soil water limitation, and $\theta_{\max }$ is the soil water content where limitation by soil water no longer exists. At first, the observed $G_{c}$ was compared with $D$. $Q$ was compared with $G_{c}$ divided by $f_{1}(D), T_{a}$ was compared with $G_{c}$ divided by $f_{1}(D) f_{2}(Q)$, and $\theta$ was compared with $G_{c}$ divided by $f_{1}(D) f_{2}(Q) f_{3}\left(T_{a}\right)$.

All the above parameter values were estimated by the gradient-based L-BFGS-B algorithm in the "optim" function in R software ( $R$ Core Team 2016), which minimizes the variance between the structural characteristics of the observed $G_{c}$ and the estimated $G_{c}$. Of the parameters, $G_{c r e f}$ and $m$ showed large variations between sites (Oren et al. 1999, Herbst et al. 2008). On the contrary, other parameters like $\delta$ showed very conservative characteristics regardless of the difference in stand structure (Ewers et al. 2008). This indicates that structural characteristics of the stand can be assumed to be related to $G_{c r e f}$ and $m$, but not to the other parameters.

To test the compatibility of the stand transpiration model with various environmental and sapwood area conditions, three model parameter set-ups were compared with a four-year continually measured stand transpiration data from eight plots. The first model used optimized parameter values for each plot and each year (hereinafter, the E1 model). The second model used $G_{c r e f}$ and $m$ estimated by the quadric relationship between SA and the other optimized parameter values in each plot in the first measurement year (hereinafter, the E2 model). The third model used the same values of $G_{c r e f}$ and $m$ as the E2 model, with the mean values of the plots for the other parameters (hereinafter, the E3 model). The performance of each model was compared by the overall coefficient of determination for 4 years, and correlation coefficients were used to compare the performance of models on each growing season.

\section{Statistical analysis}

The sensitivities of sap flux density against environmental variables were tested before model development. The parameters for describing canopy conductance $\left(G_{c}\right)$ response to $D$ variations ( $G_{\text {cref }}$ and $m$ ) were calculated with boundary-line analysis (Schäfer et al. 2000). The data recorded on low $D(<0.6 \mathrm{kPa})$ conditions were excluded in boundary-line analysis. The parameters for radiation sensitivity $(\delta)$ were determined by employing leastsquares method on regressing the relationship between observed $G_{c}$ divided by $f_{1}(D)$ and $Q$. The parameters for temperature sensitivity $\left(T_{\min }, T_{\max }\right.$, and $\left.T_{\mathrm{opt}}\right)$ were also determined by least-square method on the regression of the relationship between observed $G_{c}$ divided by $f_{1}(D) f_{2}(Q)$ and $T_{a}$. The same method was applied on the parameters for soil moisture sensitivity $\left(\theta_{\min }\right.$ and $\left.\theta_{\max }\right)$ using observed $G_{c}$ divided by $f_{1}(D)$ $f_{2}(Q) f_{3}\left(T_{a}\right)$ and $\theta$.

The performance of each model (E1, E2, and E3) was compared by an overall coefficient of determination for 4 years, and correlation coefficients, mean absolute error (MAE) and mean bias error (MBE) were used to compare the performance of models on each growing season. All analyses were conducted in R ( $R$ Core Team 2016).

\section{Results}

\section{Environmental variables}

Environmental conditions showed interannual variations over the 4-year study period. $T_{\mathrm{a}}$ was similar during the study period (Fig. 1a). Annual mean Q highest in 2012 and lowest in 2014 (Fig. 1b). Notably, the annual mean $D$ was similar among the first 3 years but was highest in 2015 (Fig. 1C). The first two years were generally wet and the last two years were dry (Fig. 1d). These conditions resulted in a distinct combination of environmental variables during the measurement years. In general, 2012 was a wet year with high light, 2013 was a wet year with low light, 2014 was a dry year with a humid atmospheric condition, and 2015 was a dry year with a dry atmospheric condition (Fig. 1a-d).

\section{Environmental constraints on canopy \\ conductance}

Fig. 2 shows the relationships between environmental variables $\left(D, Q, T_{a}\right.$, and $\theta$ ) and canopy conductance $\left(G_{c}\right)$. Each plot in Fig. 1 represents the limiting interaction of each environmental variable during the 2012 growing season. The results of $P_{1}$ for the first measurement year are only shown here, but the same processes were conducted on other plots and for other years.

\section{Relationship between parameter values} and sapwood area

There were large inter-plot variations in $m$ and $G_{\text {cref. }}$ The maximum values of $m$ (1.37 $\left.\mathrm{mm} \mathrm{d}^{-1} \mathrm{kPa}^{-1}\right)$ and $G_{\text {cref }}\left(1.74 \mathrm{~mm} \mathrm{~d}^{-1}\right)$ were approximately $70 \%$ higher than the minimum 


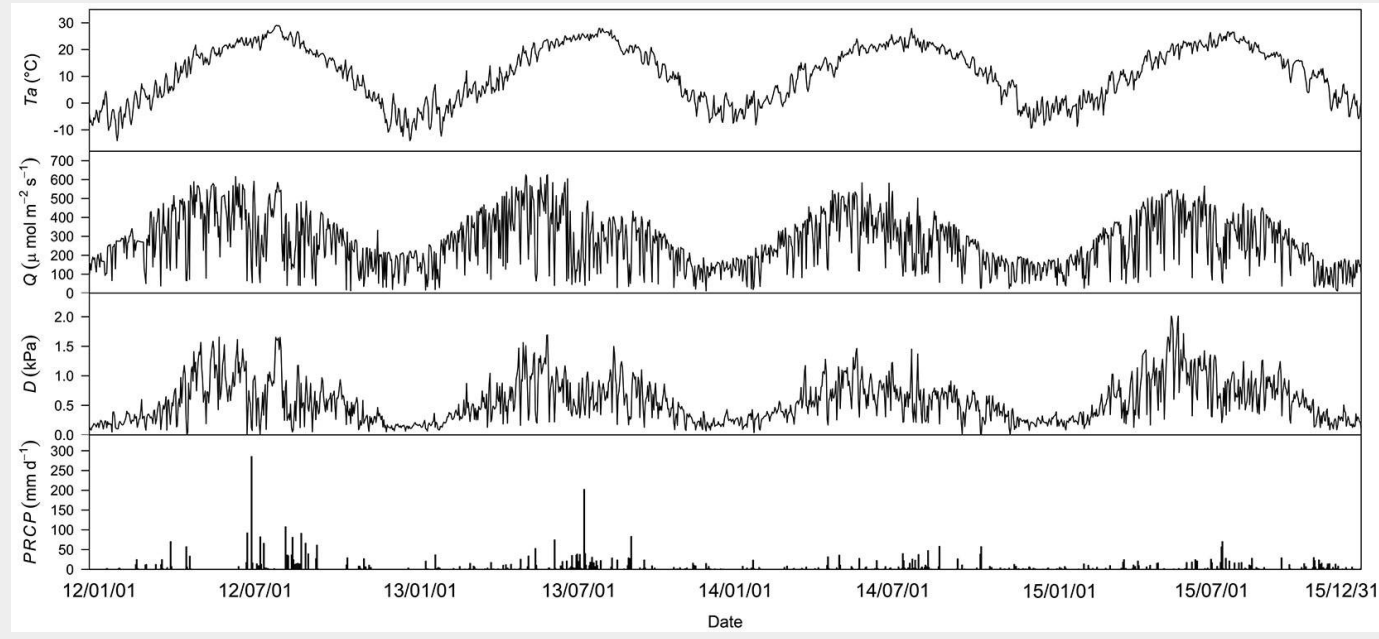

Fig. 1 - Meteorological conditions from 2012 to 2015. (a) Daily mean air temperature $\left(T_{\mathrm{a}}\right)$; (b) daily mean photosynthetically active radiation (Q); (c) daily mean vapor pressure deficit (D); (d) daily precipitation $(P R C P)$.

values of $\mathrm{m}\left(0.79 \mathrm{~mm} \mathrm{~d}^{-1} \mathrm{kPa}^{-1}\right)$ and $G_{\text {cref }}$ variation among them than $G_{\text {cref }}, m$, and $\delta$ $\left(1.06 \mathrm{~mm} \mathrm{~d}^{-1}\right) . \delta$ showed a variation among (minimum $T_{\mathrm{opt}}=18.5^{\circ} \mathrm{C}$ and maximum $T_{\mathrm{opt}}=$ the plots as well (maximum $\delta=0.63$ and $21.1^{\circ} \mathrm{C}$ ). minimum $\delta=0.40) . T_{\text {opt }}$ exhibited a smaller nificant correlations with the stand sapwood area (Fig. 3a, Fig. 3b). The second-order regression explains $90.5 \%$ of the variation in $m(P<0.001)$ and $85.8 \%$ of that in
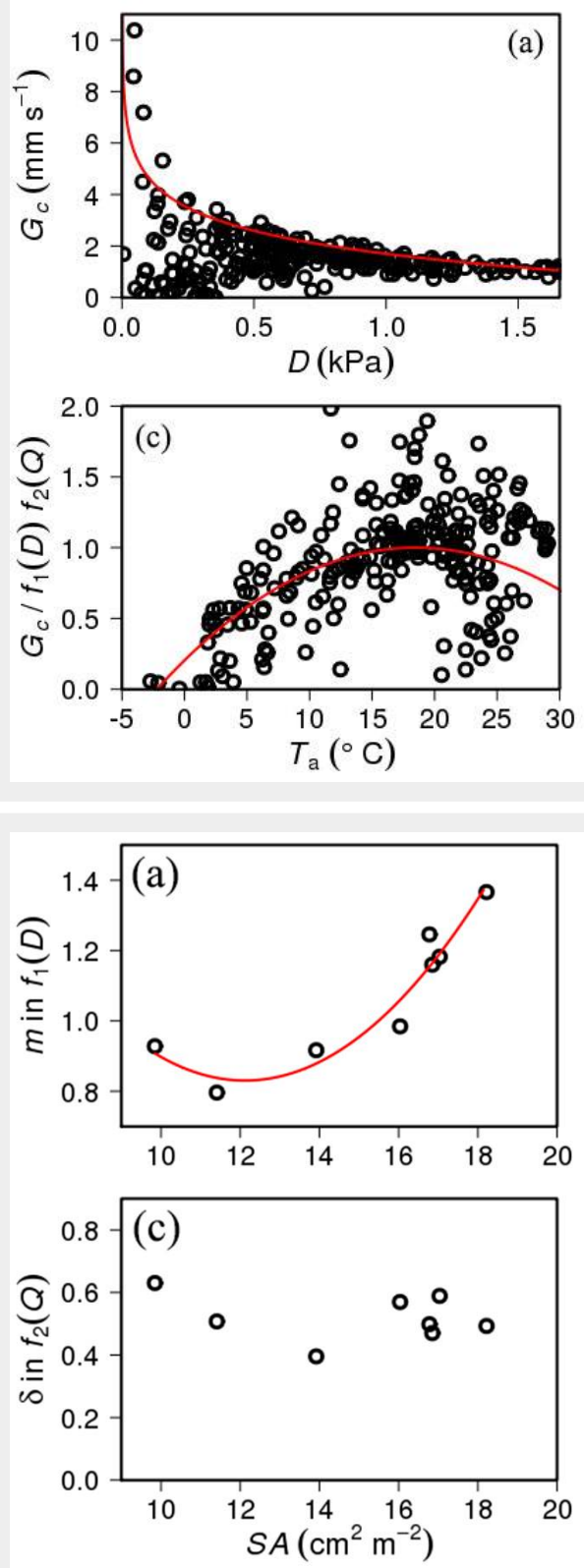
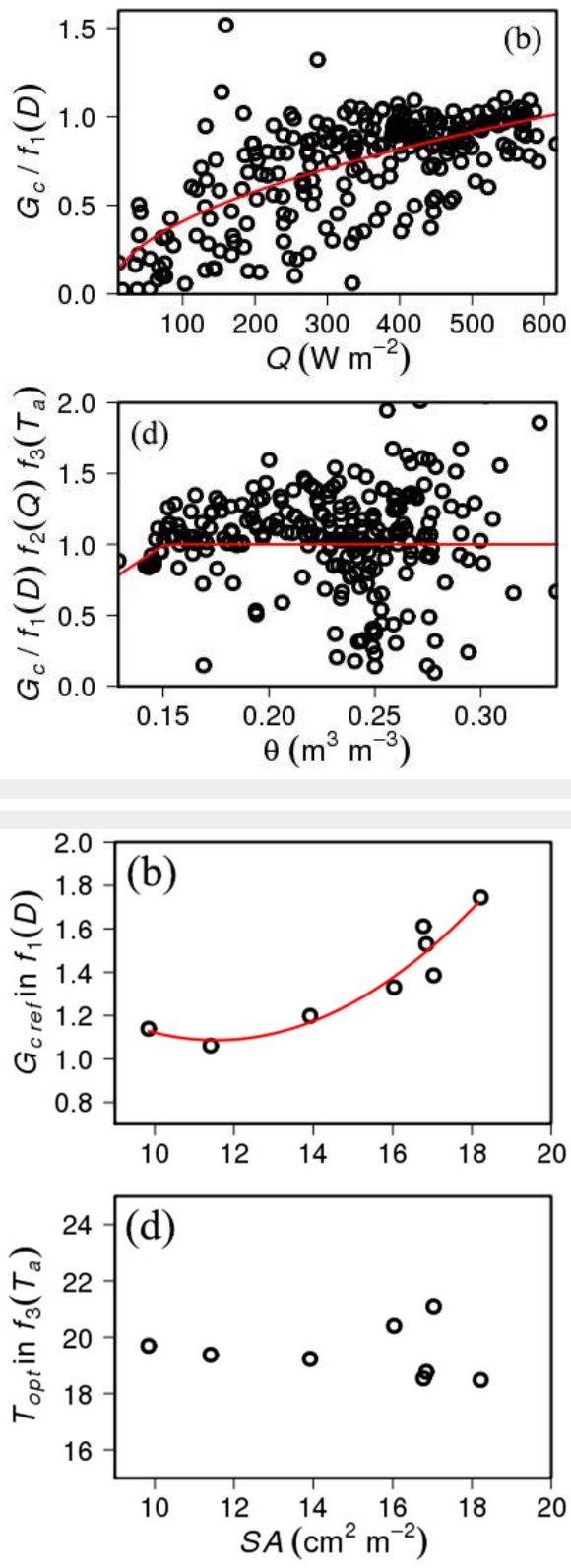

Fig. 2 - Relationships (a) between vapor pressure deficit $(D)$ and canopy conductance $\left(G_{c}\right)$, (b) between photosynthetic active radiation (Q) and $G_{c}$ divided by estimated $G_{c}$ using $D$ only $\left(f_{1}(D)\right),(c)$ between air temperature $\left(T_{a}\right)$ and $G_{c}$ divided by estimated $G_{\mathrm{c}}$ by using $D$ and $Q\left(f_{1}(D) f_{2}(Q)\right)$, and $(d)$ between volumetric soil water content $(\vartheta)$ and $G_{c}$ divided by estimated $G_{c}$ by using $D, Q$, and $T_{a}$ $\left(f_{1}(D) f_{2}(Q) f_{3}\left(T_{a}\right)\right)$. The red line in each plot indicates the function expressing the response of $G_{c}$ to $D, Q, T_{a}$, and $\vartheta$, respectively. The data from single plot and single growing season were shown.

Fig. 3 - Relationship (a) between stand sapwood area (SA) and the slope $(m)$ in $f_{1}(D),(b)$ between SA and reference canopy conductance $\left(G_{\text {cref }}\right)$ in $f_{1}(D)$, (c) between $S A$ and the regression coefficient $(\delta)$ in $f_{2}(Q)$, and $(d)$ between SA and optimum air temperature $\left(T_{\text {opt }}\right)$ in $f_{3}\left(T_{a}\right)$. The red lines indicate statistically significant regression between $\mathrm{SA}$, and (a) $m$ and (b) $G_{\text {cref }}$, respectively. 
Fig. 4 - Time series of observed daily transpiration $\left(E_{T}\right)$ for $P 1$ in 2012 and ET estimated by stom atal conductance model (a) using $D$ only, (b) D and $Q$, (c) D, $Q$, and $T_{a}$, and (d) using all of variables $\left(D, Q, T_{a}\right.$ and 9$)$. The figures on the right side show the correlation between the estimated $E_{\mathrm{T}}$ and observed $E_{\mathrm{T}}$.

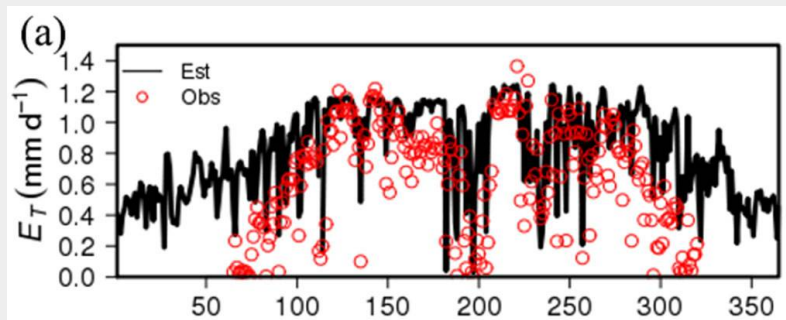

(b)

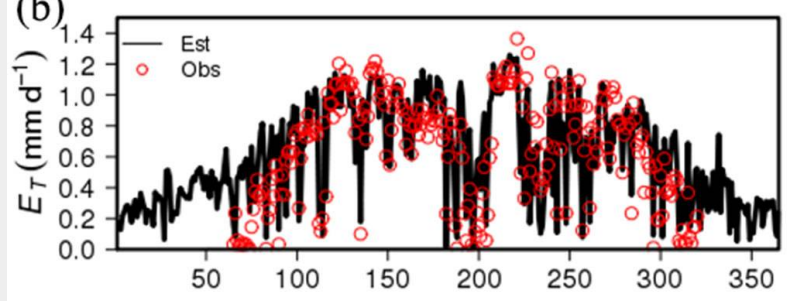

(c)
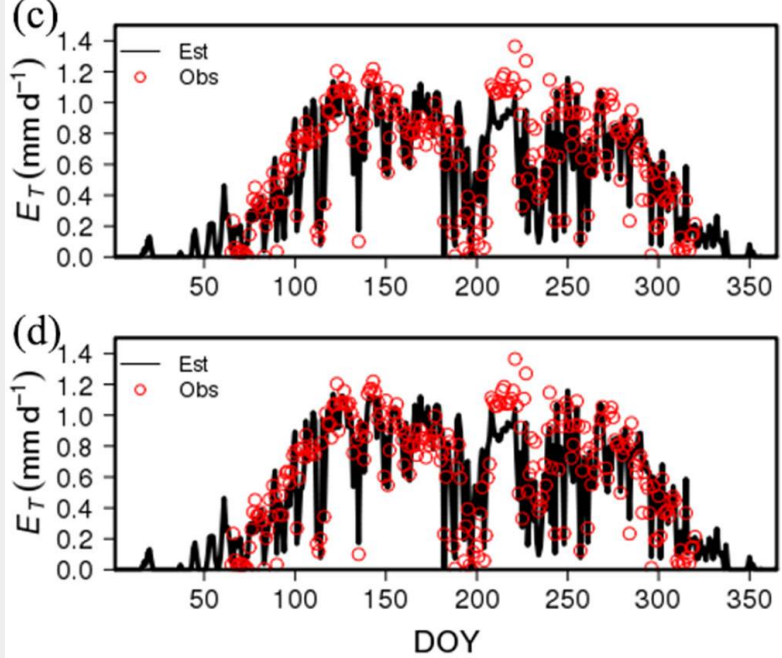
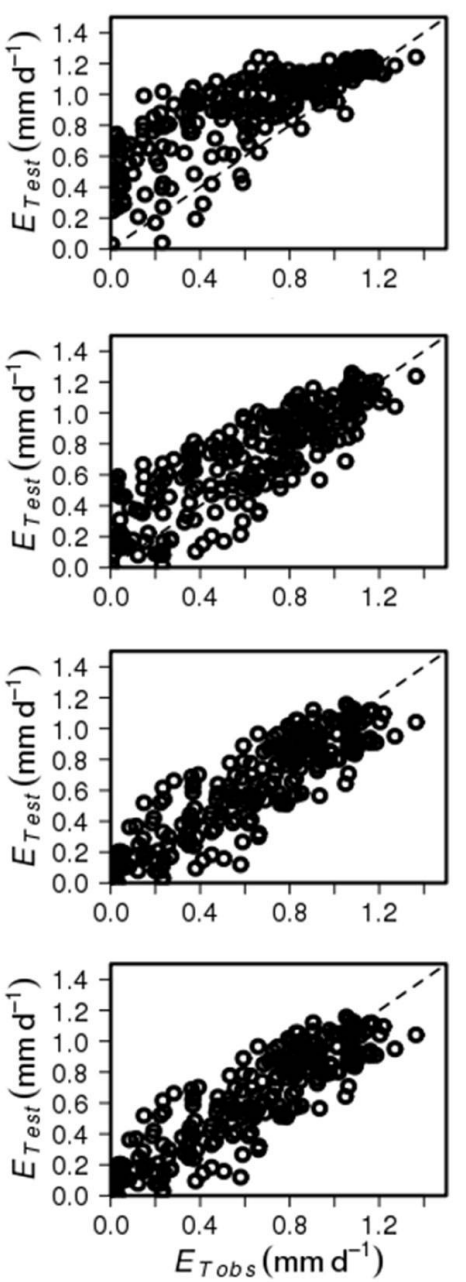

$G_{\text {cref }}(P<0.001)$. The regression lines were determined as $m=0.014 \mathrm{SA}^{2}-0.362 \mathrm{SA}+$ 3.02, and $G_{\text {cref }}=0.014 \mathrm{SA}^{2}-0.334 \mathrm{SA}+3.016$, respectively. The other two parameters did not show a significant correlation with the SA (Fig. 3C, Fig. 3d).

\section{Stand transpiration estimated by the} combination of limiting functions

Fig. 4 shows the serial time steps in the estimation of stand transpiration. At first, stand transpiration was calculated by canopy conductance estimated by using only $f_{1}(D)$. This caused an overestimation in the spring, monsoon, late autumn, and winter seasons, when $Q$ was generally low, and resulted in a relatively low determination co- efficient (adj. $R^{2}=0.624$ - Fig. 3a). When limitation by $Q$ was considered, errors in spring, monsoon, and autumn were reduced, but still showed considerable overestimation in winter. The determination coefficient was slightly increased (adj. $R^{2}=$ 0.705 - Fig. 3b). These errors in winter decreased by considering a limitation by $T_{a}$. The estimated $E_{T}$ reproduced the seasonal variation in the observed $E_{\mathrm{T}}$, and the determination coefficient significantly increased (adj. $R^{2}=0.805-$ Fig. $\left.3 C\right)$. The limitation by soil water content had little effect on stand transpiration estimation, and the determination coefficient slightly increased (adj. $R^{2}$ $=0.807-$ Fig. $3 \mathrm{~d}$ ).

\section{Evaluating model performance}

Fig. 5 shows the relationship between the observed stand transpiration and estimated transpiration using an E1 model (Fig. 4a), E2 model (Fig. 4b), and E3 model (Fig. 4c). As parameters were estimated by less measurement data periods, model performance was decreased, but estimated $E_{T}$ by most simple model (E3) still showed good agreements with measured $E_{T}$. The estimated $E_{\mathrm{T}}$ by the optimized parameters for each year and plot was strongly correlated with the observed $E_{T}(r=0.97, P<0.001$, $M A E=9.33, M B E=-7.3)$. The use of SA-related parameters reduced the correlation between the estimated $E_{T}$ and observed $E_{\mathrm{T}}(r=0.88, P<0.001, M A E=19.24, \mathrm{MBE}=$
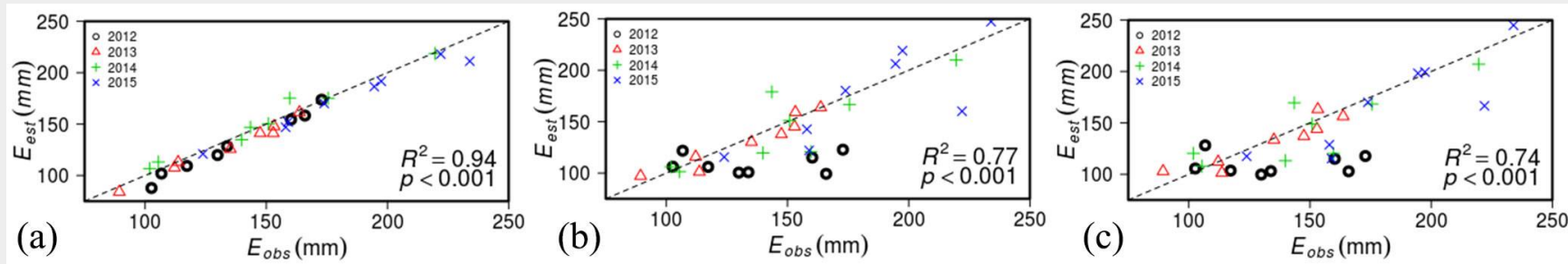

Fig. 5 - Relationship between observed annual stand transpiration for 4 years (2012-2015) and estimated stand transpiration from 8 plots by E1 model (a), by E2 model (b), and by E3 model (c). 

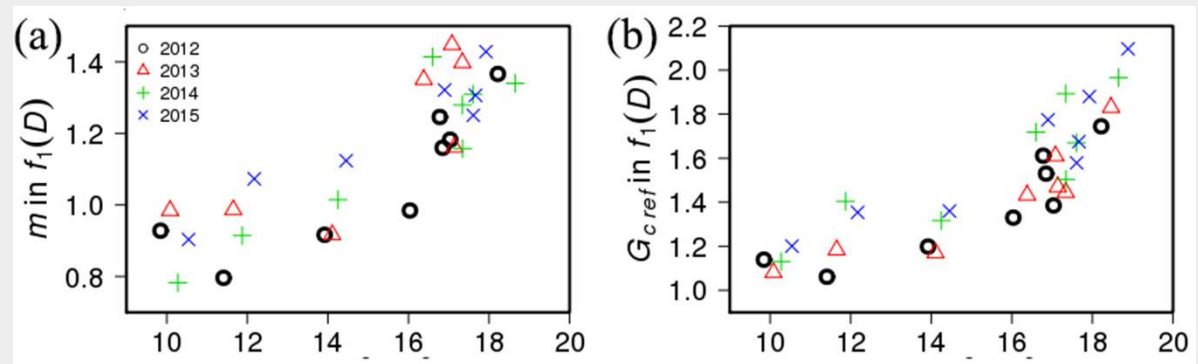

Fig. 6 - Interannual variation in relationship between (a) stand sapwood area (SA) and the slope $(m)$ in $f_{1}(D)$; (b) SA and reference canopy conductance $\left(G_{\text {cref }}\right)$ in $f_{1}(D)$; (c) SA and regression coefficient $(\delta)$ in $f_{2}(Q)$; and (d) SA and optimum air temperature $\left(T_{\text {opt }}\right)$ in $f_{3}\left(T_{\mathrm{a}}\right)$.
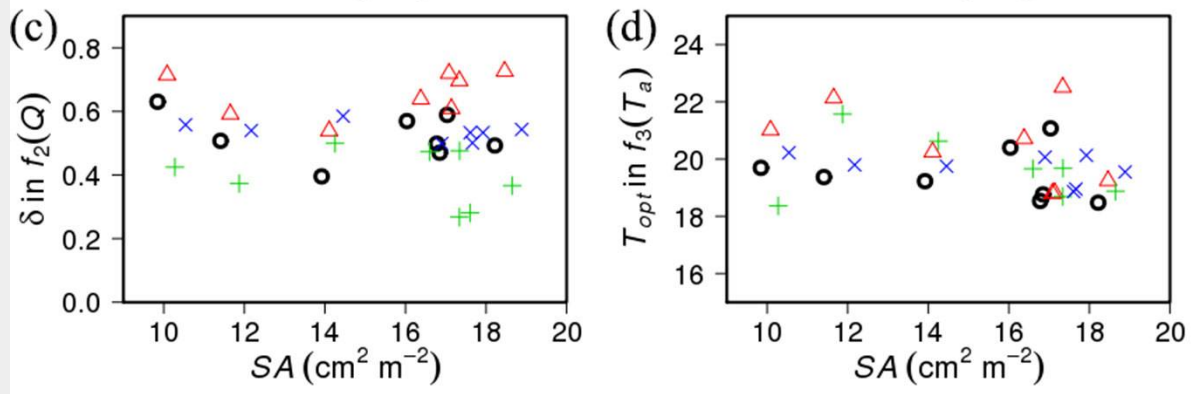

-10.76). The correlation coefficient showed a reduction over year, and was the highest in $2012(r=0.98, P<0.001)$ and the lowest in $2014(r=0.80, P=0.016)$. The other two years showed intermediate correlations (in 2013, $r=0.87, P=0.005$, in 2015, $r=0.82, P$ $=0.012$ ). The use of the plot's mean parameter values slightly reduced the correlation coefficient $(r=0.86, P<0.001, M A E=19.24$, $M B E=-12.25)$. Same in the previous model, the correlation was highest in $2012(r=$ $0.96, P<0.001)$ and lowest in $2014(r=0.73$, $P=0.039$ ).

\section{Interannual variation in parameters}

In general, the parameter values in each limiting function were relatively conservative and showed minor interannual variations (Fig. 6, Tab. S1 in Supplementary material). The $m$ and $G_{\text {cref }}$ showed similar relationships with SA during 4 growing seasons, and less variation was observed in $G_{\text {cref }}$ than $m$. The radiation sensitivity, $\delta$, showed relatively large interannual variation than other parameters (Fig. 6c). These interannual variations in $\delta$ were related to the annual mean $\theta$ (Fig. 7). The $\theta$ variation does not explain the inter-plot differences in $\delta$, but the mean $\delta$ was highest in 2013 when annual mean $\theta$ was the highest and was lowest in 2014 when $\theta$ was the lowest.

\section{Discussion}

\section{Sensitivity of canopy conductance to} environmental and structural variables

The developed stand transpiration model successfully reproduced interannual and seasonal variations in the observed $E_{T}$ in eight plots with different sapwood areas for four years (Fig. 4, Fig. 5). D was the most significant limiting factor in canopy conductance and explained $62 \%$ of temporal variations in $E_{T}$ alone. The incorporation of limitations by other environmental variables increased model performance slightly (Fig. 4b, Fig. 4c), but $\theta$ did not influence $E_{\mathrm{T}}$ estimation (Fig. $5 \mathrm{~d}$ ). One reason that the relation between soil water status and $E_{T}$ is not significant may be that $\theta$ is not a limiting factor in investigated forests, or at least during the first measurement period (during the 2012 growing season) when empirical relationships are analysed. The $\theta$ related reduction in $G_{c}$ was not observed in other temperate forests (Komatsu et al.
Fig. 7 - Relationship between interannual variation of parameter for canopy conductance sensitivity to radiation $(\delta)$ and annual mean soil water content $(\theta)$ of each plot.

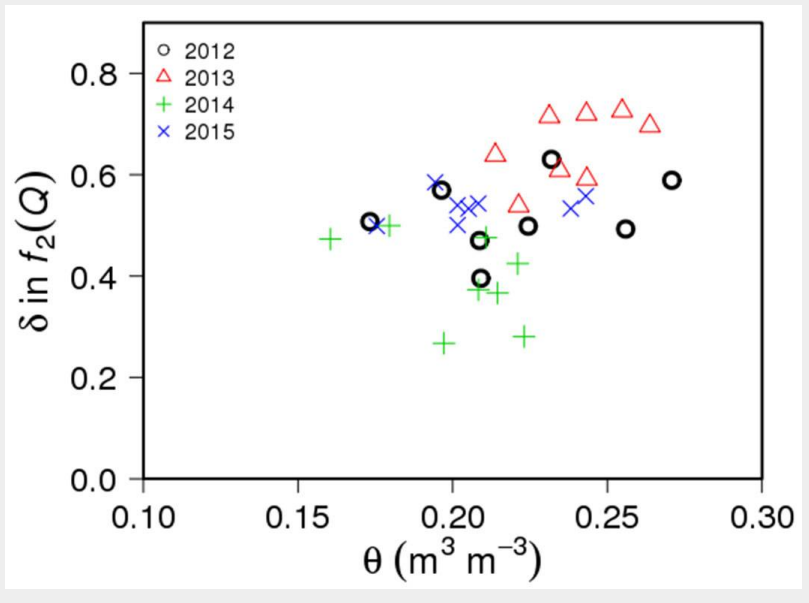

2006), but significant soil water limitation effects have been reported elsewhere (Tanaka et al. 2002, Kim et al. 2008).

The increased model performance in spring, autumn, and monsoon season by incorporation of $Q$ limitation (Fig. 4b) is caused by water availability. The Asian monsoon region generally experiences dry periods before and after summer monsoon (Zhang \& Zhou 2015), and this could lead to a decline in hydraulic conductance by embolism associated with $D$ stress (Duursma et al. 2008). Monsoon reduces water stress, and tree water use is further affected by the available energy. Limitation due to $T_{a}$ has a dominant effect on $G_{c}$ in winter and early spring. $G_{c}$ shows its optimum under $T_{a}$ conditions between 15 to 20 ${ }^{\circ} \mathrm{C}$ (Gash et al. 1989), and starts decreasing when $T_{a}$ is below $15{ }^{\circ} \mathrm{C}$ (Granier et al. 2000a).

$G_{\text {cref }}$ and $m$ showed significant interactions with stand sapwood area (Fig. 3). In general, $G_{\text {cref }}$ has a positive relationship with stand leaf area, the ratio of sapwoodto-leaf area, and the inverse of canopy height (Novick et al. 2009). However, the $\mathrm{G}_{\mathrm{c}} \mathrm{SA}$ relationship found in this study was different from that of previous studies, which reported saturation of canopy conductance at high LAI $\left(>6 \mathrm{~m}^{2} \mathrm{~m}^{-2}-\right.$ Granier et al. 200ob). This was due to low stand density and sapwood area. The LAl estimated by a site-specific allometric equation (Ryu et al. 2014) ranged from 1.93 to 4.41 (Tab. 1) and was much lower than the reported LAI $(\approx 6)$ at saturation of the observed $G_{c}$.

\section{Interannual variation in parameters}

The conservative characteristics of parameter values in each limiting function (Fig. 6) was partly caused by the physical characteristics of the target species. Pinus species generally showed isohydric characteristics (Klein et al. 2011, Roman et al. 2015). They constantly regulated water loss 
within certain ranges to reduce the variation in leaf water potential (Buckley 2005). In isohydric species, $G_{c r e f}$ and $m$ showed a conservative relationship, regardless of the difference in species and climatic conditions (Oren et al. 2001, Ewers et al. 2005), which was also shown in this study. Furthermore, leaf water potential was considered to be regulated within relatively constant ranges regardless of soil water status. This led to similar relations between $D$ and $G_{c}$ under a variety of climatic conditions. These results were different from the previous study which reported interannual variations in $D$ sensitivity with soil moisture conditions (Tor-ngern et al. 2017). However, the limited effects of soil moisture were also reported due to the use of deep soil water under drought periods (Poyatos et al. 2007b), or monsoon caused moist conditions when atmospheric evaporative demand was high in the summer season.

There was an interaction between interannual variations in radiation sensitivity $(\delta)$ and soil water availability ( $\theta-$ Fig. 7$)$. Both soil water availability and energy input by radiation control the forest transpiration, and the relative importance between them could vary by soil water conditions. Under sufficient soil water conditions, radiation limits the transpiration which causes higher $G_{c}$ sensitivity to radiation, but the sensitivity could be reduced when transpiration was limited by soil water availability. The model that used the site-specific and year-to-year parameter values showed the best performance. However, the models using estimated or general mean parameter values also showed acceptable $\left(r^{2}>\right.$ o.74) performance in annual stand transpiration estimation.

\section{Limitations}

Empirical approaches exhibit reasonable performance in limited ranges of environmental conditions. As they have been developed under constrained ranges of environmental conditions, extreme climatic conditions like drought reduce their capability in terms of estimations of $G_{c}$ (Gao et al. 2002). Thus, the applicable range of empirical models depends on the generality of the observed relationship and the range in which it is valid.

There are sources of uncertainty in upscaling from sapflux density measurements to stand transpiration. Although the measured radial and circumferential variations of sapflux density (Moon et al. 2015) were used for upscaling, the assumption of similar radial variations, regardless of stand sapwood area, could be invalid because they can be significantly altered by stand density (Medhurst et al. 2002). Moreover, the relationship between SA and LAI can be affected by stand density. In less competitive plots, trees can access more water and nutrients and allocate more biomass to above-ground. This could make trees support more leaf area per unit basal area in low-density stands (Shibuya et al. 2005). The assumption of same sapwood depth regardless of tree size could also increase the uncertainty of stand transpiration estimation. However, due to even-aged stand conditions and similar canopy positions in this study, differences in sapwood depth among trees may be small. Moreover, since most of sap was transported through the outer sapwood area, uncertainties in inner sapwood depth did not result in large errors in stand transpiration estimation.

In the simplification of the Penman-Monteith equation, aerodynamic conductance is assumed to be infinite. This assumption is generally accepted for coniferous forests (Herbst 1995), but forest stand structures and surface roughness affect aerodynamic conductance. As a result, applying the simplified Penman-Monteith equation on a stand with low aerodynamic conductance causes an overestimation of canopy conductance.

\section{Implications for forest management}

Similar methods have been applied to predict $E_{T}$ at various sites (Granier et al. 2000b, Benyon et al. 2017). However, the empirical relationships in those studies could not be directly applied to other specific forests or tree species. The $E_{T}$ model developed in this study can be very useful to estimated changes in $E_{T}$ in Korean pine forests with forest management-induced structural changes.

The $E_{\mathrm{T}}$ model helps estimate spatial variation in $E_{\mathrm{T}}$ and total forest water use with the combined use of a forest digital map and National Forest Inventory data. The most powerful aspect of this model is the use of the simple and easily measurable forest structural variable (SA). However, this model application is constrained to Pinus koraiensis forests at present. The direct application of the empirical relationship found in this study to other types of forest can generate erroneous estimations of $E_{\mathrm{T}}$, but the concept underlying it is useful for developing an $E_{\mathrm{T}}$ model for forests composed of other species.

Furthermore, this model can help to estimate forest productivity when combining stand water use with water use efficiency estimated by other approaches such as stable isotope discrimination measurements (Turnbull et al. 2002, Wang et al. 2014).

\section{Conclusion}

This study found the main environmental constraint in stand transpiration and developed a stand transpiration model that related the stand structural variable with canopy conductance. The stand transpiration was regulated mostly by vapor pressure deficit. The stomatal sensitivity to vapor pressure deficit and reference canopy conductance were increased with stand sapwood area. The model successfully reproduced changes in stand transpiration against changes in stand sapwood area and climatic conditions.
The results indicate that measurement on a single growing season on stands with various sapwood areas can generate a reliable stand transpiration model for monospecies' forests. Moreover, the use of simple forest structural variables can lend generality to this method and enable an easy application to other forests. This can help us understand the mechanisms underlying spatial and temporal variations in forest water use.

\section{Acknowledgments}

This work was supported by Korea Forest Service (S211315L020120, S111215L020110, 2020185D10-2022-AA02) and Korea Meteorological Administration (KIMPA-2012-00012). We are also thankful for supports of the Mt. Teahwa Seoul National University Forest and its staff.

\section{References}

Bae SW, Jang SC, Lee KJ, Lee ST, Sung JH, Kim SH, Kim KH, Hwang JH, Kim JS, Jung JM, Kim HS (2011). Management strategy for integrity of Korean pine plantation. Research Report 11-11, Korean Forest Research Institute, Seoul, South Korea, pp. 19-20.

Benyon RG, Nolan RH, Hawthorn SN, Lane PN (2017). Stand-level variation in evapotranspiration in non-water-limited eucalypt forests. Journal of Hydrology 551: 233-244. - doi: 10.1016/j.jhy drol.2017.06.002

Blanken PD, Black TA (2004). The canopy conductance of a boreal aspen forest, Prince Albert National Park, Canada. Hydrological Processes 18: 1561-1578. - doi: 10.1002/hyp.1406 Buckley TN (2005). The control of stomata by water balance. New Phytologist 168: 275-292. doi: 10.1111/j.1469-8137.2005.01543.x

Caldwell PV, Miniat CF, Elliott KJ, Swank WT, Brantley ST, Laseter SH (2016). Declining water yield from forested mountain watersheds in response to climate change and forest mesophication. Global Change Biology 22: 2997-3012. doi: 10.1111/gcb.13309

Cosme LH, Schietti J, Costa FR, Oliveira RS (2017). The importance of hydraulic architecture to the distribution patterns of trees in a central Amazonian forest. New Phytologist 215: 113-125. - doi: 10.1111/nph.14508

Duursma RA, Kolari P, Perämäki M, Nikinmaa E, Hari P, Delzon S, Loustau D, Ilvesniemi H, Pumpanen J, Mäkelä A (2008). Predicting the decline in daily maximum transpiration rate of two pine stands during drought based on constant minimum leaf water potential and plant hydraulic conductance. Tree Physiology 28: 265-276. - doi: 10.1093/treephys/28.2.265

Ewers BE, Gower ST, Bond-Lamberty B, Wang CK (2005). Effects of stand age and tree species on canopy transpiration and average stomatal conductance of boreal forests. Plant Cell and Environment 28: 660-678. - doi: 10.1111/j.1365-30 40.2005.01312.x

Ewers BE, Mackay DS, Tang J, Bolstad PV, Samanta S (2008). Intercomparison of sugar maple (Acer saccharum Marsh.) stand transpiration responses to environmental conditions from the Western Great Lakes Region of the United States. Agricultural and Forest Meteo- 
rology 148: 231-246. - doi: 10.1016/j.agrformet.20 07.08 .003

Gao Q, Zhao P, Zeng X, Cai X, Shen W (2002). A model of stomatal conductance to quantify the relationship between leaf transpiration, microclimate and soil water stress. Plant, Cell and Environment 25: 1373-1381. - doi: 10.1046/j.1365-30 40.2002.00926.x

Gash JHC, Shuttleworth WJ, Lloyd CR, André JC, Goutorbe JP, Gelpe J (1989). Micrometeorological measurements in Les Landes Forest during HAPEX-MOBILHY. Agricultural and Forest Meteorology 46: 131-147. - doi: 10.1016/0168-1923 (89)90117-2

Granier A (1987). Evaluation of transpiration in a Douglas-fir stand by means of sap flow measurements. Tree Physiology 3: 309-320. - doi: 10.1093/treephys/3.4.309

Granier A, Biron P, Lemoine D (2000a). Water balance, transpiration and canopy conductance in two beech stands. Agricultural and Forest Meteorology 100: 291-308. - doi: 10.1016/S01681923(99)00151-3

Granier A, Loustau D, Breda N (2000b). A generic model of forest canopy conductance dependent on climate, soil water availability and leaf area index. Annals of Forest Science 57: 755765. - doi: 10.1051/forest:2000158

Harris PP, Huntingford C, Cox PM, Gash JH, Malhi $Y$ (2004). Effect of soil moisture on canopy conductance of Amazonian rainforest. Agricultural and Forest Meteorology 122: 215227. - doi: 10.1016/j.agrformet.2003.09.006

Herbst M (1995). Stomatal behaviour in a beech canopy: an analysis of Bowen ratio measurements compared with porometer data. Plant, Cell and Environment 18: 1010-1018. - doi: 10.1111/ j.1365-3040.1995.tboo611.x

Herbst M, Rosier PT, Morecroft MD, Gowing DJ (2008). Comparative measurements of transpiration and canopy conductance in two mixed deciduous woodlands differing in structure and species composition. Tree Physiology 28: 959970. - doi: 10.1093/treephys/28.6.959

Hornbeck J, Adams M, Corbett E, Verry E, Lynch $J$ (1993). Long-term impacts of forest treatments on water yield: a summary for northeastern USA. Journal of Hydrology 150: 323-344. doi: 10.1016/0022-1694(93)90115-P

Jarvis P (1976). The interpretation of the variations in leaf water potential and stomatal conductance found in canopies in the field. Philosophical Transactions of the Royal Society of London B: Biological Sciences 273: 593-610. doi: 10.1098/rstb.1976.0035

Jarvis P, McNaughton K (1986). Stomatal control of transpiration: scaling up from leaf to region. In: “Advances in Ecological Research", vol. 15, Elsevier, pp. 1-49. - doi: 10.1016/So065-2504(08) 60119-1

Kelliher FM, Leuning R, Schulze ED (1993). Evaporation and canopy characteristics of coniferous forests and grasslands. Oecologia 95: 153163. - doi: 10.1007/BFo0323485

Kim HS, Oren R, Hinckley TM (2008). Actual and potential transpiration and carbon assimilation in an irrigated poplar plantation. Tree Physiology 28: 559-577. - doi: 10.1093/treephys/28.4. 559

Klein T, Cohen S, Yakir D (2011). Hydraulic adjustments underlying drought resistance of Pinus halepensis. Tree Physiology 31: 637-648. - doi: 10.1093/treephys/tpro47

Komatsu H, Kang Y, Kume T, Yoshifuji N, Hotta N (2006). Transpiration from a Cryptomeria japonica plantation, part 2: responses of canopy conductance to meteorological factors. Hydrological Processes 20: 1321-1334. - doi: 10.1002/hyp.60 94

Komatsu $\mathrm{H}$, Shinohara $\mathrm{Y}$, Kumagai $\mathrm{T}$, Kume T, Tsuruta K, Xiang Y, Ichihashi R, Tateishi M, Shimizu T, Miyazawa Y, Nogata M, Laplace S, Han T, Chiu CW, Ogura A, Saito T, Otsuki K (2014). A model relating transpiration for Japanese cedar and cypress plantations with stand structure. Forest Ecology and Management 334: 301-312. doi: 10.1016/j.foreco.2014.08.041

Kumagai T, Tateishi M, Shimizu T, Otsuki K (2008). Transpiration and canopy conductance at two slope positions in a Japanese cedar forest watershed. Agricultural and Forest Meteorology 148: 1444-1455. - doi: 10.1016/j.agrformet. 2008.04.010

Medhurst JL, Beadle C (2002). Sapwood hydraulic conductivity and leaf area - Sapwood area relationships following thinning of a Eucalyptus nitens plantation. Plant, Cell and Environment 25 (8): 1011-1019. - doi: 10.1046/j.1365-3040.2002. 00880.x

Medhurst JL, Battaglia M, Beadle CL (2002). Measured and predicted changes in tree and stand water use following high-intensity thinning of an 8-year-old Eucalyptus nitens plantation. Tree Physiology 22: 775-784. - doi: 10.1093/ treephys/22.11.775

Moon M, Kim T, Park J, Cho S, Ryu D, Kim HS (2015). Variation in sap flux density and its effect on stand transpiration estimates of Korean pine stands. Journal of Forest Research 20: 8593. - doi: 10.1007/s10310-014-0463-0

Moon M, Kim T, Park J, Cho S, Ryu D, Suh S, Kim HS (2016). Changes in spatial variations of sap flow in Korean pine trees due to environmental factors and their effects on estimates of stand transpiration. Journal of Mountain Science 13: 1024-1034. - doi: 10.1007/s11629-015-3793-2

Novick K, Oren R, Stoy P, Juang JY, Siqueira M, Katul G (2009). The relationship between reference canopy conductance and simplified hydraulic architecture. Advances in Water Resources 32: 809-819. - doi: 10.1016/j.advwatres.2 009.02 .004

Oren R, Sperry JS, Ewers BE, Pataki DE, Phillips $N$, Megonigal JP (2001). Sensitivity of mean canopy stomatal conductance to vapor pressure deficit in a flooded Taxodium distichum L. forest: hydraulic and non-hydraulic effects. Oecologia 126: 21-29. - doi: 10.1007/s0044200004 97

Oren R, Sperry JS, Katul G, Pataki DE, Ewers B, Phillips N, Schäfer K (1999). Survey and synthesis of intra-and interspecific variation in stomatal sensitivity to vapour pressure deficit. Plant, Cell and Environment 22: 1515-1526. - doi: 10.104 6/j.1365-3040.1999.00513.x

Poyatos R, Martínez-Vilalta J, Cermák J, Ceulemans R, Granier A, Irvine J, Köstner B, Lagergren F, Meiresonne L, Nadezhdina N (2007a). Plasticity in hydraulic architecture of Scots pine across Eurasia. Oecologia 153: 245-259. - doi: 10.1007/s00442-007-0740-0

Poyatos R, Villagarcía L, Domingo F, Piñol J,
Llorens P (2007b). Modelling evapotranspiration in a Scots pine stand under Mediterranean mountain climate using the GLUE methodology. Agricultural and Forest Meteorology 146: 13-28. - doi: 10.1016/j.agrformet.2007.05.003

R Core Team (2016). R: a language and environment for statistical computing. R Foundation for Statistical Computing, Vienna, Austria. [online] URL: http://www.r-project.org

Rodrigues TR, Vourlitis GL, Lobo F, Santanna FB, De Arruda PH, Nogueira J (2016). Modeling canopy conductance under contrasting seasonal conditions for a tropical savanna ecosystem of south central Mato Grosso, Brazil. Agricultural and Forest Meteorology 218: 218-229. - doi: 10.1016/j.agrformet.2015.12.060

Roman D, Novick K, Brzostek E, Dragoni D, Rahman F, Phillips R (2015). The role of isohydric and anisohydric species in determining ecosystem-scale response to severe drought. Oecologia 179: 641-654. - doi: 10.1007/s00442-015-33809

Ryu D, Moon M, Park J, Cho S, Kim T, Kim HS (2014). Development of allometric equations for $V$ age-class Pinus koraiensis in Mt. Taehwa plantation Gyeonggi-do. Korean Journal of Agricultural and Forest Meteorology 16 (1): 2938. - doi: 10.5532/KJAFM.2014.16.1.29

Schäfer K, Oren R, Tenhunen J (2000). The effect of tree height on crown level stomatal conductance. Plant, Cell and Environment 23: 365-375. - doi: 10.1046/j.1365-3040.2000.00553.x

Shibuya M, Hasaba H, Yajima T, Takahashi K (2005). Effect of thinning on allometry and needle-age distribution of trees in natural Abies stands of northern Japan. Journal of Forest Research 10: 15-20. - doi: 10.1007/s10310-004-0093$z$

Simonin K, Kolb T, Montes-Helu M, Koch G (2007). The influence of thinning on components of stand water balance in a ponderosa pine forest stand during and after extreme drought. Agricultural and Forest Meteorology 143: 266-276. - doi: 10.1016/j.agrformet.2007.01. 003

Tanaka K, Kosugi Y, Nakamura A (2002). Impact of leaf physiological characteristics on seasonal variation in $\mathrm{CO}_{2}$, latent and sensible heat exchanges over a tree plantation. Agricultural and Forest Meteorology 114: 103-122. - doi: 10.1016/ S0168-1923(02)00128-4

Tang J, Bolstad PV, Ewers BE, Desai AR, Davis KJ, Carey EV (2006). Sap flux-upscaled canopy transpiration, stomatal conductance, and water use efficiency in an old growth forest in the Great Lakes region of the United States. Journal of Geophysical Research: Biogeosciences 111 (G2): 1-12. - doi: 10.1029/2005JG000083

Tor-ngern $P$, Oren R, Oishi AC, Uebelherr JM, Palmroth S, Tarvainen L, Ottosson-Löfvenius $M$, Linder S, Domec JC, Näsholm T (2017). Ecophysiological variation of transpiration of pine forests: synthesis of new and published results. Ecological Applications 27: 118-133. - doi: 10.100 2/eap.1423

Turnbull MH, Whitehead D, Tissue DT, Schuster WS, Brown KJ, Engel VC, Griffin KL (2002). Photosynthetic characteristics in canopies of Quercus rubra, Quercus prinus and Acer rubrum differ in response to soil water availability. Oecologia 130: 515-524. - doi: 10.1007/s00442-001- 
0842-z

Vertessy RA, Watson FGR, O'Sullivan SK (2001). Factors determining relations between stand age and catchment water balance in mountain ash forests. Forest Ecology and Management 143: 13-26. - doi: 10.1016/S0378-1127(00)00501-6 Wang $\mathrm{H}$, Zhao P, Zou L, McCarthy $\mathrm{H}$, Zeng X, Ni $\mathrm{G}$, Rao X (2014). $\mathrm{CO}_{2}$ uptake of a mature Acacia mangium plantation estimated from sap flow measurements and stable carbon isotope discrimination. Biogeosciences 11: 1393.
Wang Y, Papanatsiou M, Eisenach C, Karnik R, Supplementary Material

Williams M, Hills A, Lew VL, Blatt MR (2012).

Systems dynamic modeling of a guard cell Cl- Tab. S1 - Interannual variations in paramechannel mutant uncovers an emergent homeo- ter values of each limiting function.

static network regulating stomatal transpiration. Plant Physiology 160: 1956-1967. - doi: 10.1104/pp.112.207704

Zhang L, Zhou T (2015). Drought over East Asia: a review. Journal of Climate 28: 3375-3399. - doi: 10.1175/JCLI-D-14-00259.1
Fig. S1 - Plot mean sapflux density $\left(J_{S}\right)$ and observed canopy conductance $\left(G_{c}\right)$ for 4 growing season (2012-2015).

Link: Park_3291@supploo1.pdf 